\section{Multiple infections and associated risk factors among non-injecting cocaine users in Argentina}

\author{
Infecciones múltiples y factores de riesgo \\ asociados entre usuarios de cocaína \\ no inyectable en Argentina
}

\footnotetext{
1 Intercambios: Asociación Civil para el Estudio y Atención de Problemas Relacionados con las Drogas, Buenos Aires, Argentina. 2 Asociación Civil El Retoño, Buenos Aires, Argentina. 3 Centro Nacional de Re-educación Social, Buenos Aires, Argentina. ${ }^{4}$ Centro Nacional para Diagnóstico e Investigación en Endemo-Epidemias, Administración Nacional de Laboratorios e Institutos de Salud Dr. Carlos G. Malbrán, Buenos Aires, Argentina. ${ }^{5}$ Hospital de Clínicas José de San Martín, Universidad de Buenos Aires, Buenos Aires, Argentina.

${ }_{6}$ Center for Drug Use and HIV Research, National Development and Research Institutes, New York, U.S.A. 7 Facultad de Medicina, Universidad de Buenos Aires, Buenos Aires, Argentina.

Correspondence D. Rossi

Intercambios: Asociación Civil para el Estudio y Atención de Problemas Relacionados con las Drogas. $A v$. Corrientes 2548, $2^{\circ}$ " $D$ ", CP C1046AAQ, Ciudad de Buenos Aires, Argentina. drossi@intercambios.org.ar
}

\begin{abstract}
The aim of this study was to estimate the seroprevalence rates of human immunodeficiency virus (HIV), hepatitis B virus (HBV, core antibody), hepatitis $C$ virus (HCV), and syphilis infections and analyze associated risk factors among 504 non-injecting cocaine users (NICU) in Buenos Aires, Argentina. Participants were interviewed in face-to-face sessions through a short structured questionnaire. Using venipuncture, $10 \mathrm{~mL}$ of blood was collected. Seroprevalence rates were: $H I V$ (6.3\%), HBV (9\%), HCV (7.5\%), and VDRL (4.2\%). The risk of being infected with HIV, HBV, and HCV was significantly associated with having had a sex partner who was either a drug injector or who was known to be HIV positive. HIV and HCV infections were associated with former imprisonment, and HCV was associated with having been tattooed. Because of the rising number of NICU and the multiple infections detected, it is essential to implement prevention strategies focused on this population.
\end{abstract}

Cocaine; Street Drugs; HIV; Hepatitis; Risk Factors

\author{
Diana Rossi 1 \\ Graciela Radulich 2 \\ Estela Muzzio ${ }^{3}$ \\ Jorge Naveira ${ }^{3}$ \\ Sergio Sosa-Estani 4 \\ Jorge Rey 5 \\ Gloria Griemberg 5 \\ Samuel R. Friedman 6 \\ Liliana Martínez-Peralta 7 \\ Mercedes Weissenbacher 7
}

\section{Introduction}

An increase in the use of non-injected cocaine has been observed in Argentina over the past 15 years 1 . Most studies on the prevalence of infections that are either bloodborne or sexually acquired among drug users in Argentina have been conducted among injecting drug users (IDU), over $95 \%$ of whom inject cocaine. Several studies have demonstrated a high seroprevalence of human immunodeficiency virus (HIV), hepatitis $\mathrm{B}$ virus (HBV), and hepatitis C virus (HCV) 2,3,4,5 among the drug-injecting population. Cocaine, which was regarded several decades ago as a drug consumed exclusively by affluent people, has now extended into low-income sectors that were formerly far from its reach.

There is some evidence that non-injecting drug use increases HIV infection as well as other sexually transmitted diseases (STD), particularly through unprotected sexual activity 6,7,8,9. Although there are available data on injecting drug use and its association with different infections in Argentina, little is known about the infections associated with the use of non-injecting cocaine. This knowledge is not only crucial to develop interventions targeting this population but also to determine if the mechanisms of transmission bear similarities or differences with other countries. Preliminary studies carried out between 1987 and 1994 among non-injecting drug users (NIDU) in Greater Buenos Aires, Argentina, sug- 
gest an HIV seroprevalence that varied between $2 \%$ and $4 \%$.

The aim of this study was to acquire a better knowledge about the seroprevalence of HIV, HBV, $\mathrm{HCV}$, and syphilis as well as risk factors associated with the infection of these pathogens among non-injecting cocaine users in Buenos Aires and its surroundings.

\section{Material and methods}

A descriptive cross-sectional study was conducted among 504 non-injecting cocaine users (NICU) in Buenos Aires and its surroundings.

The National Center for Social Re-education (a governmental treatment center for drug users) recruited NICU who were either outpatients or hospitalized in the same institution. In addition, the civil associations El Retoño and Intercambios recruited NICU in different outof-treatment settings using snowball sampling. $29.6 \%(149 / 504)$ of the total sample were in a drug treatment program and $70.4 \%(355 / 504)$ were recruited in out-of-treatment settings. The study population included males and females 18 years of age or older, living in Buenos Aires or its surroundings, who, in the interview, reported having consumed cocaine or its derivatives in a non-injecting fashion (either sniffed or smoked) at least once in the 90 days prior to the interview, had never injected drugs, and agreed to participate by signing an informed consent. Volunteers were not paid for participating in the study. IDU were screened out by offering them testing and counseling if they wished to know their serological status, but were not included in the analyzed results.

Participants were interviewed in face-to-face sessions through a short structured questionnaire assessing socio-demographic characteristics, drug use and sexual histories, criminal records, and previous infections with HIV or syphilis. Using venipuncture, $10 \mathrm{ml}$ of blood was collected. Volunteers were informed that the results of the survey would be strictly confidential.

Two weeks after the first interview, volunteers were informed of their test results and were provided with information and counseling on prevention of STD. Volunteers who tested positive for any of these agents were referred to corresponding infectious disease clinics for appropriate care. Those who tested HBV negative were offered free immunization against HBV. The volunteers in our study demonstrated a high level of commitment. Eighty-three percent of participants returned to receive their test results and appropriate counseling.
International and national ethical guidelines for biomedical research involving human subjects were strictly followed 10 , and Institutional Review Board (IRB) approval was obtained from the School of Medicine, Buenos Aires University. Informed consent was obtained from all participants.

HIV antibody screening was performed using the enzyme immunoassay (EIA) and particle agglutination (Genscreen HIV-1/2 Version 2 and SFD HIV-1/2 PA, Bio-Rad Laboratories, Hercules, U.S.A/Fujirebio Diagnostics Inc., Malvern, U.S.A.) methods with Western blot confirmation (WB HIV: New Lab Blot I, Bio-Rad Laboratories, Hercules, U.S.A.). HBV core antibody assays were conducted using the Core CM Abbott AxSYM System (Abbott Laboratories, Abbott Park, U.S.A.). HBV surface antigen assay was performed using the Abbot AxSYM System HbsAg(v2) (Abbott Laboratories, Abbott Park, U.S.A.). HBV infection was defined by the presence of HbcAb with or without HbsAg. HCV testing was performed using HCV version 3.0, Abbott AxSYM System (Abbott GmbH Diagnostika, Wiesbaden, Germany). Based on both the methodology and the criteria utilized for HCV diagnosis in the study population (no supplementary testing was utilized), there may be around $10 \%$ of false positive tests.

To screen for syphilis, the Venereal Disease Research Laboratory slide test was utilized (VDRL test, Wiener Lab Group, Rosario, Argentina).

\section{Sample size}

We planned to enroll a sample size of 493 NICU, assuming a seroprevalence of $3 \%$, a $95 \%$ significance level, a beta error of $20 \%$, and a precision of $1.5 \%$.

\section{Statistical analysis}

Univariate analysis was performed on all variables of the database. Differences between infected and non-infected participants were analyzed using parametric and nonparametric statistical methods. Prevalence rates and trends were compared and analyzed using the chi-squared and Fisher's exact tests. Means were compared by ANOVA or Kruskal-Wallis tests. Risks were analyzed by odds ratio (OR), and the confidence interval was obtained by a significance level of 95\%. Univariate descriptive analysis and bivariate and multivariate analyses using non-conditional logistic regression were used to evaluate the association of risk factors. We performed models through multivariable analysis of the relationships among HIV, HCV, and HBV infections and the set of exposure variables. Age and gender 
were included as control variables in the model. Data were entered and analyzed using Access 2000 (Microsoft Corp., U.S.A.) and Epi Info 2000 (Centers for Disease Control and Prevention, Atlanta, U.S.A.). The selected variables were those that were statistically significant at the alpha $=$ 0.05 level in the bivariate analysis and that had biological plausibility.

\section{Results}

\section{Socio-demographic aspects}

The study was conducted from September 2002 through March 2003 among 504 individuals who agreed to participate in the study. The mean age was $28.2 \pm 8.3$ years, ranging from 18 to 65 years. Fifty-five percent of volunteers were between 20 and 29 years of age, and $69.8 \%$ of volunteers were male. Volunteers recruited by the three different organizations showed no differences in terms of age, health care coverage, employment, and education. Ninety-six percent of participants were Argentine; $70 \%$ had a complete elementary education, $12.9 \%$ had finished high school, and $8.2 \%$ had completed university studies. Some $38.7 \%$ of the volunteers lived with their parents, $26.2 \%$ lived with a sex partner, $12.5 \%$ lived alone, $6.2 \%$ lived with a friend, and $16.5 \%$ lived with relatives. Of all the participants, $43.2 \%$ were employed, $40.4 \%$ received either family or state support, $4.4 \%$ lived on illegal sources of support, and $12 \%$ depended on other sources of support.

A high percentage reported having been detained at least once at the police station (59.8\%) and/or had been in prison (16.3\%). Among all detainees, $36.3 \%$ reported that they had been arrested for drug-related reasons. Participants were not questioned about other reasons for their arrest.

\section{Drug consumption}

Within the three months prior to the interview, the majority of study participants sniffed cocaine as well as consumed alcohol and/or cannabis. Reported consumption of coca paste and crack was much less frequent.

Regarding frequency of drug use, $23 \%$ of NICU reported using drugs daily, $61.3 \%$ used drugs in the company of others: $51.6 \%$ with friends, $12.5 \%$ with sex partners, $2 \%$ with family members, and $6 \%$ with other categories of people. Most NICU shared elements such as straws (45.3\%), pipes, or stems (59.6\%), and cigarettes (64.2\%) if they consumed with other drug users. Considering only the out-of-treatment interviewees, $74.1 \%$ had made at least one attempt to quit drugs, but only $25.3 \%$ had received formal treatment.

The illegal drugs most frequently used at the initiating stage of consumption, in decreasing order, were cannabis (27\%) and cocaine (18\%), followed by nonprescription medicines, inhalants (glues and solvents), and other drugs. The mean initiating age for any drug was $15.9 \pm 4.9$ years; for cocaine it was $18.5 \pm 5.5$ years; for coca paste (also called basuco in some Latin American countries, coca paste is an intermediate step in the manufacturing process between coca leaves and purified cocaine) it was $21.4 \pm 6.4$ years; and for crack it was $22.6 \pm 6.6$ years.

One hundred percent of the NICU reported non-injecting consumption of cocaine or its derivatives at least once in the 90 days prior to the interview.

When volunteers were asked about the drugs most frequently consumed over the past three months prior to the interview, they reported (multiple responses were allowed) the following: cocaine $83.7 \%$, cannabis $60.7 \%$, nonprescription medicines $8.9 \%$, coca paste $10.7 \%$, and crack $1.2 \%$. Of those who used cocaine most frequently, $98.6 \%$ sniffed it, while $5.4 \%$ reported that they smoked it.

\section{Sexual practices}

Some $43.2 \%$ of subjects reported that they had not used condoms with casual partners in their last sexual intercourse, and $66.5 \%$ reported no condom use with steady partners. Having current same-sex and opposite-sex relations was reported by $9.9 \%(15 / 152)$ of women and $10.8 \%$ (38/352) of men; ever having had sexual relations with an IDU by $13.2 \%$; ever having had sex with an HIV-infected partner by $19.9 \%$; and a steady sex partner that was a drug user (either injecting or non-injecting) by $36.5 \%$.

\section{History of HIV}

Among the volunteers, 55.6\% reported having had at least one HIV serological test. Of these, $6.1 \%(17 / 280)$ reported they were HIV-positive, $88.2 \%(247 / 280)$ reported that they were HIVnegative, and $5.7 \%(16 / 280)$ did not answer or were unaware of their serological status. Only $82.4 \%$ of those who reported HIV infection were confirmed as infected, whereas $3.7 \%$ of those who reported being HIV-negative were infected.

Self-reported HIV-positive status was associated with more condom use with a steady sex partner in the last sexual intercourse $(p=0.01$; $\mathrm{OR}=0.3$ [0.1-0.9]). Of those who knew they were HIV-positive, $62.5 \%$ had used condoms in their 
last intercourse with a steady partner, while of those who were unaware of their HIV status, only $32.5 \%$ had used condoms in their last intercourse with a steady partner.

\section{Seroprevalence of HIV, HBV, HCV,} and VDRL reactivity

83.4 percent of participants returned for the twoweek follow-up visit to receive their test results and appropriate counseling. There were no significant differences in the demographic factors that allowed predicting participants' return.

Among the 504 NICU in this study, HIV seroprevalence was $6.3 \%$, HBV $9 \%$, HCV $7.5 \%$, and VDRL reactivity $4.2 \%$ (Table 1 ). Nineteen percent $(94 / 504)$ of NICU were infected with one or more infectious agent (HIV, HBV, HCV, or syphilis). Among those infected, $65 \%$ were infected with only one infectious agent, $27 \%$ were co-infected with two, $7 \%$ with three, and $1 \%$ with all four infectious agents.

No difference was observed in the prevalence of HIV infection by gender (men, $6.8 \%$; women $5.3 \%$ ) in the overall study population. Excluding men who have sex with men, HIV infection was $7 \%$ in men $(22 / 314)$ and $5.3 \%$ in women $(8 / 152)$.

The highest HIV infection rate was in the 30to-39-year-old group (14\%), which also showed the highest HCV rate (14.7\%). The highest HBV prevalence was in the 30-to-39-year-old and 40to-49-year-old groups and did not differ between genders $(p=0.13)$. Presence of hepatitis B surface antigen (HBsAg) was $0.6 \%(3 / 502)$ in the total sample and $6.7 \%(3 / 45)$ in the core antibodypositive subjects.

Prevalence of VDRL reactivity also did not vary by gender or age. None of these infections varied significantly by education, employment, or health care status.

NICU infected with any of the infectious agents were also highly likely to be co-infected with another pathogen (Table 2).

HIV infection was significantly associated with HCV, HBV, and VDRL positivity (Figure 1).

\section{Risk factors}

Among the total sample, bivariate analysis to estimate risk of HIV infection based on risk exposure variables showed a significant association with having had an HIV-positive partner, both in men $(\mathrm{OR}=7.43$, 95\%CI: 3.13-17.60) and women (OR = 17.57, 95\%CI: 3.32-92.96), or an IDU sex partner, both in men (OR $=4.51,95 \% \mathrm{CI}$ : 1.71-11.90) and women $(\mathrm{OR}=7.77,95 \% \mathrm{CI}$ : 1.73-34.77). Among men, a history imprisonment was associated with HIV (OR $=5.35$, 95\%CI: 2.24-12.75). No risk corre- lates were observed among other risk variables related to either drug use or sexual behavior history (including men who have sex with men, women who have sex with women, and sex trade).

HCV infection was associated with a history of having had either a former HIV-positive partner or an IDU partner as well as with having been tattooed, detained at a police station, or imprisoned (Table 3). Seventy-nine percent of HCV-infected individuals had tattoos, which also was associated with having been in prison $(\mathrm{p}<$ 0.001; OR $=2.4[1.4-4.4]$ ). During counseling, an $\mathrm{HCV}$-infected volunteer stated that many prisoners slashed their arms with the same razor blades in a kind of blood brother ritual, which could explain HCV transmission. Importantly, former IDU may not have been detected during the interviews, and the serodiagnosis strategy may have yielded some false-positive results: either could help explain the high infection rate.

HBV infection was associated with having had a former IDU partner $(\mathrm{OR}=2.68,95 \% \mathrm{CI}$ : 1.14-5.90) or an HIV-positive partner (OR = 3.09, 95\%CI: 1.49-6.26)

NICU with a history of tuberculosis (TB) were found to be at an increased risk of being infected with HIV, HBV, and HCV ( $\mathrm{p}<0.05$ ).

There was an association between history of TB and HIV, HBV, and HCV seropositivity.

In the multivariate analysis (Table 4), both the history of having had an HIV-positive partner and having been in prison remained associated with the risk of HIV infection. Condom use with sex partners in the last sexual relation was found to be a protective behavior (it is likely that condom use was induced by the knowledge of their HIV positivity - data not shown). Risk factors for HCV were age, having had an IDU partner, and both having had a tattoo and having been in prison. With regard to $\mathrm{HBV}$, multivariate analysis showed as risk factors age, having had an IDU partner (lifetime), as well as practicing unprotected sex when on drugs. Risk of self-reported syphilis was associated with participating in homosexual or bisexual practices and having been in prison.

\section{Discussion}

This was the first study conducted among NICU in Argentina that associated the seroprevalence of HIV, HCV, HBV, and syphilis infections with their risk factors. The inclusion criterion for volunteers was non-injecting consumption of cocaine within 90 days prior to the interview. The results cannot be generalized to the entire NICU population in the study area, since the recruitment strategies may introduce participation 
Prevalence rates of infection/exposure with HIV, hepatitis C virus (HCV), hepatitis B virus (HBV), and Venereal Disease Research Laboratory slide test (VDRL) reactivity among 504 non-injecting cocaine users from Buenos Aires, Argentina, 2002-2003 *.

\begin{tabular}{|c|c|c|c|c|c|}
\hline \multirow[t]{2}{*}{ Variables/Categories } & \multicolumn{4}{|c|}{ Subjects with indicated infection/exposure (\%) } & \multirow{2}{*}{$\begin{array}{c}\text { Total } \\
\left(N^{* \star \star}\right)\end{array}$} \\
\hline & HIV & HBV ** & $\mathrm{HCV}$ & VDRL & \\
\hline Total & 32 (6.3) & $45(9.0)$ & $38(7.5)$ & $21(4.2)$ & 504 \\
\hline \multicolumn{6}{|l|}{ Gender } \\
\hline Female & $8(5.3)$ & $18(11.9)$ & $8(5.3)$ & $6(3.9)$ & 152 \\
\hline Male & $24(6.8)$ & $27(7.7)$ & $30(8.8)$ & $15(4.3)$ & 352 \\
\hline \multicolumn{6}{|l|}{ Age (years) } \\
\hline $18-19$ & $0(0.0)$ & $1(2.0)$ & $1(2.0)$ & $0(0.0)$ & 51 \\
\hline $20-29$ & $13(4.7)$ & $14(5.1)$ & $15(5.4)$ & $12(4.3)$ & 278 \\
\hline $30-39$ & $18(14.0)$ & $24(18.6)$ & $19(14.7)$ & $6(4.7)$ & 129 \\
\hline $40-49$ & $0(0.0)$ & $6(18.2)$ & $3(9.1)$ & $2(6.1)$ & 33 \\
\hline$\geq 50$ & $1(7.7)$ & $0(0.0)$ & $0(0.0)$ & $1(7.7)$ & 13 \\
\hline \multicolumn{6}{|l|}{ Education } \\
\hline Incomplete elementary & $4(8.5)$ & $5(4.9)$ & $6(12.8)$ & $2(4.3)$ & 47 \\
\hline Elementary & $25(7.2)$ & $31(10.8)$ & $26(7.4)$ & $15(4.3)$ & 349 \\
\hline High school & $3(4.6)$ & $7(8.9)$ & $5(7.7)$ & $2(3.1)$ & 65 \\
\hline Higher education & $0(0.0)$ & $2(10.6)$ & $1(2.4)$ & $2(4.9)$ & 41 \\
\hline \multicolumn{6}{|l|}{ Employed } \\
\hline Yes & $13(6.3)$ & $21(10.1)$ & $18(8.7)$ & $8(3.8)$ & 208 \\
\hline No & $19(6.5)$ & $24(8.2)$ & $20(6.8)$ & $12(4.1)$ & 292 \\
\hline \multicolumn{6}{|l|}{ Health care } \\
\hline With health care & $5(8.1)$ & $5(8.3)$ & $1(1.6)$ & $1(1.6)$ & 62 \\
\hline Without health care & $25(5.7)$ & $39(9.0)$ & $35(8.0)$ & $19(4.4)$ & 436 \\
\hline \multicolumn{6}{|l|}{ History of detainment } \\
\hline No & $11(5.4)$ & $17(8.5)$ & $6(3.0)$ & $11(5.4)$ & 202 \\
\hline Yes & $21(7.0)$ & $28(9.4)$ & $32(10.7) \#$ & $10(3.3)$ & 300 \\
\hline \multicolumn{6}{|l|}{ History of imprisonment } \\
\hline No & $17(4.1)$ & $35(8.5)$ & $22(5.3)$ & $17(4.1)$ & 415 \\
\hline Yes & 13 (16.0) \#\# & $8(9.9)$ & 16 (19.8) \#\# & $4(4.9)$ & 81 \\
\hline \multicolumn{6}{|c|}{ Detained in prison due to drugs } \\
\hline No & $13(7.5)$ & $15(8.6)$ & $20(11.5)$ & $7(4.0)$ & 174 \\
\hline Yes & $7(7.1)$ & $6(6.1)$ & $6(6.1)$ & $4(4.0)$ & 99 \\
\hline
\end{tabular}

* Based on both the methodology and the criteria utilized for HCV diagnosis in the study population (no supplementary testing was utilized), there may be some $10 \%$ of false-positive tests. There may also be up to $1 \%$ of false-positive VDRL tests;

** $\mathrm{N}$ with HBV results: 502 ;

*** Differences between the sum of absolute values for each category and the total of interviewees (504) are due to cases of "does not know or does not answer", which are not included as a category;

$\# p<0.01$;

$\#$ \# $<0.001$.

bias, e.g., by over-recruitment of especially cooperative participants or under-recruitment of less cooperative ones. Nevertheless, snowball sampling of a hidden population like cocaine users is considered representative 11 .

We recruited a young population of 504 NICU characterized by a high unemployment rate and low educational level compared to national rates for the general population of Argentina. Even though $46 \%$ of the NICU in this study reported being employed, only $12 \%$ reported having health care coverage, adding to this population's high vulnerability.

One out of five NICU was infected with at least one of the tested infectious agents. HIVinfected NICU were at an increased risk of being co-infected with HBV and HCV and syphilis, with HCV showing the highest risk of co-infection. Being infected with HIV, HBV, or HCV was significantly associated with having had an HIV- 
Table 2

Infection/exposure with HIV, hepatitis C virus (HCV), hepatitis B virus (HBV), and Venereal Disease Research Laboratory slide test (VDRL) reactivity and risk of being co-infected with other infectious agents among 504 non-injecting cocaine users from Buenos Aires, Argentina, 2002-2003.

\begin{tabular}{lcccc}
\hline Infectious agents & $\begin{array}{c}\text { Cases of co-infection } \\
\text { with at least one } \\
\text { other infectious agent }\end{array}$ & Total of cases & OR (95\%Cl) & p value \\
\hline HIV- & $62(13.1 \%)$ & 472 & & \\
HIV+ & $20(62.5 \%)$ & 32 & $10.93(4.82-25.85)$ & $<0.0001$ \\
HBV- & $49(10.7 \%)$ & 457 & $8.71(4.28-17.76)$ & $<0.0001$ \\
HBV+ & $23(51.1 \%)$ & 45 & & $<0.0001$ \\
HCV- & $56(12 \%)$ & 466 & $11.13(5.22-24.44)$ & \\
HCV+ & $23(60.5 \%)$ & 38 & $4.19(1.50-11.30)$ & $<01 *$ \\
VDRL- & $73(15.1 \%)$ & 483 & 21 & \\
VDRL+ & $9(42.9 \%)$ & 21 & \\
\hline
\end{tabular}

* Fisher's exact $p$ value.

Figure 1

Co-infection: hepatitis C virus (HCV), hepatitis B virus (HBV), and Venereal Disease Research Laboratory slide test (VDRL) reactivity rates according to HIV infection in 504 non-injecting cocaine users in Buenos Aires, Argentina, 2002-2003.

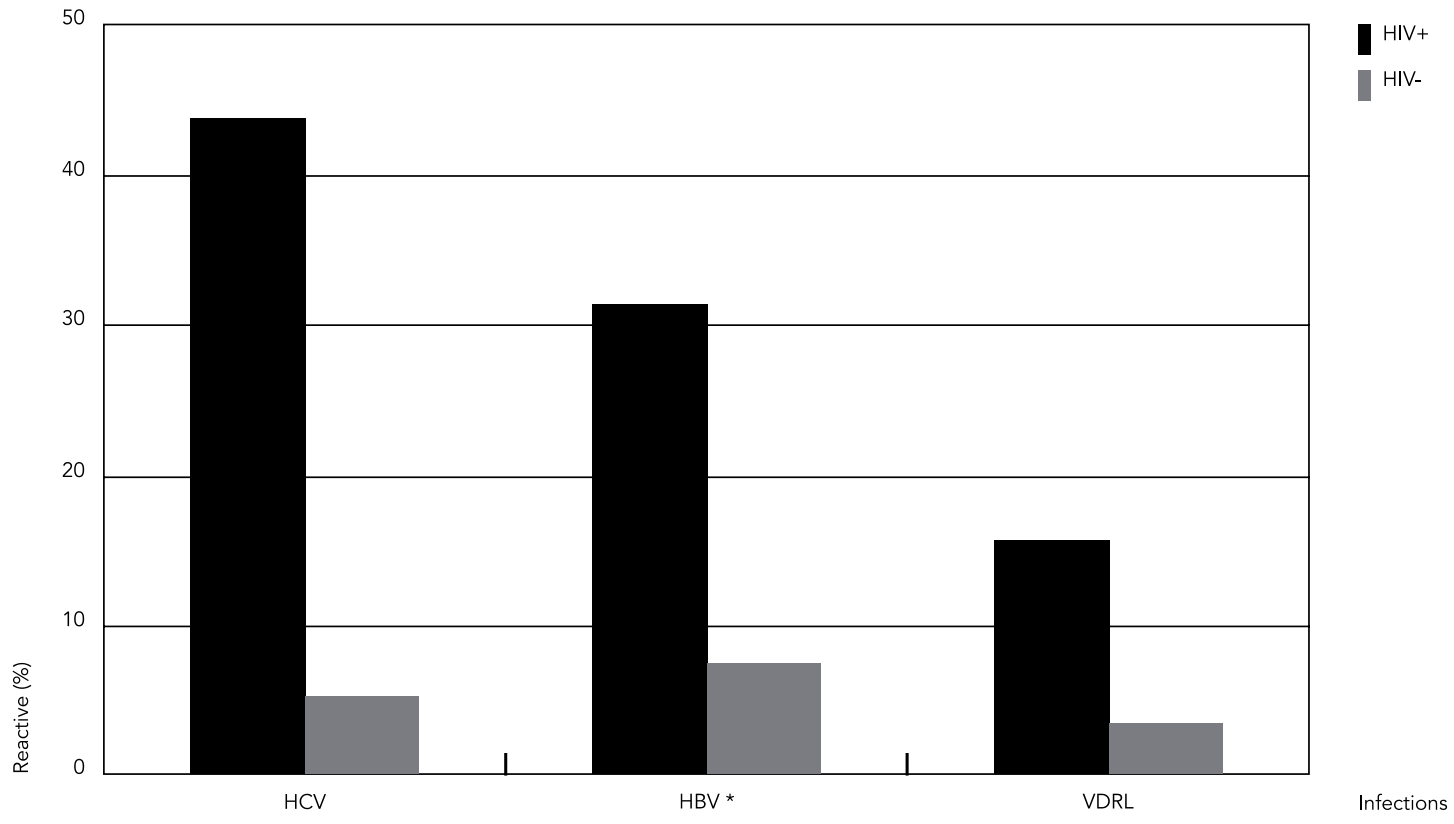

${ }^{*} \mathrm{n}=502$. 
Risk factors associated with hepatitis $\mathrm{C}$ virus (HCV) infection according to history of exposure among 504 non-injecting cocaine users from Buenos Aires, Argentina, 2002-2003.

\begin{tabular}{|c|c|c|c|c|c|c|c|}
\hline & \multicolumn{2}{|c|}{ Women exposed (\%) } & \multirow{3}{*}{$\begin{array}{c}\text { OR } \\
(95 \% \mathrm{Cl})\end{array}$} & \multicolumn{2}{|c|}{ Men exposed (\%) } & \multirow{3}{*}{$\begin{array}{c}\text { OR } \\
(95 \% \mathrm{Cl})\end{array}$} & \multirow{3}{*}{$\begin{array}{l}\text { Adjusted OR } \\
\qquad \begin{array}{c}(95 \% \mathrm{Cl}) \\
\text { W-M }\end{array}\end{array}$} \\
\hline & HCV- $(n=144)$ & $\mathrm{HCV}+(\mathrm{n}=8)$ & & HCV- $(n=322)$ & $\mathrm{HCV}+(n=30)$ & & \\
\hline & & & & & & & \\
\hline \multicolumn{8}{|l|}{ Relations with sex } \\
\hline \multicolumn{8}{|l|}{ partner or others } \\
\hline \multicolumn{8}{|l|}{ Former or present } \\
\hline IDU partner & 17.5 & 71.4 & $11.8(2.1-64.3)$ & 9.4 & 20.0 & $2.4(0.9-6.4)$ & $3.7(1.7-8.2)$ \\
\hline \multicolumn{8}{|l|}{ Former or present } \\
\hline HIV+/AIDS partner & 16.0 & 50.0 & $5.3(1.2-22.5)$ & 15.2 & 30.0 & $2.4(1.0-5.5)$ & $2.9(1.4-5.9)$ \\
\hline \multicolumn{8}{|l|}{ Tattoo } \\
\hline Had a tattoo & 49.7 & 75.0 & $3.0(0.6-15.6)$ & 63.3 & 80.0 & $2.3(0.9-5.8)$ & $2.5(1.1-5.5)$ \\
\hline \multicolumn{8}{|l|}{ Criminal record } \\
\hline Had been detained & 36.8 & 62.5 & $2.8(0.7-12.4)$ & 67.2 & 90.0 & $4.4(1.3-14.8)$ & $3.8(1.5-9.8)$ \\
\hline Had been imprisoned & 7.9 & 37.5 & $7.0(1.5-33.4)$ & 17.0 & 43.3 & $3.7(1.7-8.1)$ & $4.1(2.0-8.3)$ \\
\hline
\end{tabular}

IDU: injecting drug user.

Table 4

Multivariate analyses of risk factors associated with HIV, hepatitis B virus (HBV), and hepatitis C virus (HCV) infections and self-reported syphilis among 504 noninjecting cocaine users from Buenos Aires, Argentina, 2002-2003 (multivariate analysis adjusted by age and gender).

\begin{tabular}{|c|c|c|c|}
\hline Models/Variables & OR & $95 \% \mathrm{Cl}$ & $\mathrm{p}$ value \\
\hline \multicolumn{4}{|l|}{ Model for HIV infection } \\
\hline History of imprisonment & 3.41 & $1.36-8.51$ & $<0.01$ \\
\hline History of HIV+/AIDS partner (lifetime) & 11.34 & $4.75-27.07$ & $<0.0001$ \\
\hline Condom use with partner & 0.40 & $0.16-0.96$ & $<0.05$ \\
\hline \multicolumn{4}{|l|}{ Model for HCV infection } \\
\hline Age & 1.04 & $1.00-1.09$ & $<0.05$ \\
\hline History of IDU partner (lifetime) & 3.19 & $1.41-7.20$ & $<0.01$ \\
\hline Tattoo & 2.77 & $1.11-6.88$ & $<0.05$ \\
\hline History of imprisonment & 2.96 & $1.40-6.25$ & $<0.01$ \\
\hline \multicolumn{4}{|l|}{ Model for HBV infection } \\
\hline Age & 1.06 & $1.02-1.10$ & $<0.001$ \\
\hline History of IDU partner (lifetime) & 2.30 & $1.06-4.99$ & $<0.05$ \\
\hline Unprotected sex when on drugs & 2.20 & $1.10-4.40$ & $<0.05$ \\
\hline \multicolumn{4}{|l|}{ Model for infection with self-reported syphilis } \\
\hline Homosexual/bisexual practices & 4.07 & $1.63-10.19$ & $<0.001$ \\
\hline History of imprisonment & 4.63 & $2.14-10.01$ & $<0.001$ \\
\hline
\end{tabular}

IDU: injecting drug user. 
positive partner or an IDU partner 12 . HIV and $\mathrm{HCV}$ co-infection is particularly serious because $\mathrm{HCV}$ infection progresses more rapidly to liver damage in HIV-infected persons 13 and because $\mathrm{HCV}$ infection may have a negative impact on the course of HIV infection.

The $6.3 \%$ HIV rate in this study of NICU was slightly lower than the rate observed in Montevideo $(9.5 \%)$ 14. In New York, rates have ranged from $8.6 \%$ to $17 \%$ among never injectors in a recently published study 15 . In Brazil, HIV seroprevalence among crack smokers 16 and incidence studies showed a rate of 5.03/100 person-years at risk, none of the seroconverters having reported recent cocaine injection 17 . These data may suggest the important role of sexual transmission of HIV among non-injecting drug users in different cities of the South American region.

Some sexual risk factors were associated with HIV, HBV, and syphilis infections. We also found a protective association between knowledge of being HIV-positive and condom use with either regular or casual sex partners, which could be associated with an altruistic or solidarity-based positive attitude toward safe sex 18 . On the other hand, having unprotected sex when under the influence of drugs showed an increased risk of becoming HBV-infected.

Having had an IDU partner increased the risk of HCV infection. The non-injecting-drug population may be at greater risk of sexual transmission of $\mathrm{HCV}$ as a result of increased exposure to possibly HCV-infected IDU 3,19,20. We should also not rule out that some NICU have a history of IDU that was not reported during the interview, or another form of blood exposure with their IDU partner, such as sharing razor blades or toothbrushes. It should be added that in New York City, NIDU were more likely than IDU to have had sexual contact with the general population. If this is true in Buenos Aires, NICU may act as a bridge for HCV and HIV transmission between IDU and the broader population 6 .

The young age of initiation of drug use, including cocaine use, shows the need for effective drug prevention and harm reduction messages targeted to adolescents.

A high percentage of participants reported that they had tried to stop using drugs. Only a quarter of those recruited in out-of-treatment centers said that they had formal treatment, which could be attributable to both the limited number of drug treatment programs in the country and the scarce and deficient strategies to attract this population 21 . Moreover, most lowincome drug users cannot afford private treatment, and access to free drug treatment programs is difficult.
Considering the high seroprevalence rates in this population, the fact that participants often used drugs in the company of other drug users (mostly regarded as friends or sex partners) may pose a high risk of spreading infections.

Several types of paraphernalia were shared to consume drugs, but none of them was significantly associated with risk of infection as described in other studies 6,22.

History of imprisonment was significantly associated with HIV, HCV, and syphilis (VDRL) infection $23,24,25$. History of tattoos was only associated with $\mathrm{HCV}$ infection. A high percentage of NICU $(76 \%)$ had been either detained at a police station or imprisoned at least once. There, they may have engaged in unprotected sex with persons of the same or opposite sex, besides unhygienic tattooing. Based on our clinical practice, we know that in Argentina tattooing is very common among both drug users and prisoners: it is often carried out under unhygienic conditions while sharing both sharp tools and tattoo ink. More research and appropriate interventions should address the associations between imprisonment and infection.

Other studies among non-injecting heroin users (many of whom also used cocaine) in New York City have also shown that a history of tattooing was significantly associated with HCV infection 6,8. Infected NICU are probably an important proportion of the Buenos Aires HIV/AIDS epidemic 26.

In this study, we demonstrated the existence of multiple infections in a group of NICU in Buenos Aires. NICU appear to have been infected with HIV, HBV, and syphilis mainly through sexual transmission. HCV transmission appears to be related to having had an IDU sex partner, a tattoo, and/or having been in prison, although at least some of these infections could be due to unreported injection drug use.

Public health implications of these findings could be summarized as follows:

- NICU (as well as NIDU) should be recipients of education and other interventions aimed at preventing the spread of HIV, HBV, HCV and syphilis. Such interventions should take account of the risk factors as determined in this study as well as standard prevention methods (e.g., testing for infection and making treatment readily available, including maintenance of treatment if incarcerated; and treating all STD to reduce likelihood of acquiring or passing on HIV and probably HCV); - This implies that activities are needed in prisons for NICU in relation to HIV, HCV, and syphilis;

- Tattoo-related interventions are needed for NICU and others in relation to HCV. 


\section{Resumen}

El propósito de este estudio era estimar los índices de seroprevalencia del virus de inmunodeficiencia $h u$ mano (VIH), virus de la hepatitis B (VHB, anticuerpo core), virus de la hepatitis $C$ (VHC) e infecciones de sifilis y analizar factores de riesgo asociados entre 504 usuarios de cocaína no inyectable (UCNI) en la ciudad de Buenos Aires, Argentina. Se entrevistó a los participantes en sesiones cara a cara a través de un cuestionario estructurado corto. Usando el método de la venipunción se recogieron $10 \mathrm{~mL}$ de sangre. Las tasas de seroprevalencia fueron: VIH (6,3\%), VHB (9\%), VHC (7,5\%), y VDRL (4,2\%). El riesgo de infección por $V I H, V H B, y$ VHC se asoció significativamente a mantener relaciones sexuales con un compañerola que era consumidor de la droga inyectada o que era conocido por ser VIH positivo. Las infecciones de VIH y de VHC se asociaron a haber estado encarcelado anteriormente, $y$ la de VHC se asoció también a haber sido tatuado. Debido al número creciente de UCNI y a las infecciones múltiples detectadas, es esencial implementar estrategias de prevención centradas en esta población

Cocaína; Drogas Ilícitas; VIH; Hepatitis; Factores de Riesgo

\section{References}

1. Instituto Nacional de Estadísticas y Censos/Secretaría de Programación para la Prevención de la Drogadicción y la Lucha contra el Narcotráfico, Presidencia de la Nación. Segundo estudio nacional sobre consumo de sustancias psicoactivas. Población de 12 a 65 años. Argentina 2004. http://www.sedronar.gov.ar/PlanNacionaldedro gas/PlanNacionaldedrogas.pdf (accessed on 09/ Oct/2006).

2. Rossi D, Goltzman P, Cymerman P, Touzé G, Weissenbacher M. Human immunodeficiency virus/ acquired immunodeficiency syndrome prevention in injection drug users and their partners and children: lessons learned in Latin America - the Argentinean case. Clin Infect Dis 2003; 37 Suppl 5: S362-5.

\section{Contributors}

D. Rossi wrote the manuscript, reviewed the literature, and participated in the data collection. G. Radulich, E. Muzzio, and J. Naveira participated in the data collection. S. Sosa-Estani organized the database and analyzed the data. J. Rey and G. Griemberg performed the laboratory tests. L. Martínez-Peralta designed and coordinated the laboratory studies. S. R. Friedman provided consultation, proofreading, and scientific editing. $\mathrm{M}$. Weissenbacher designed and coordinated the research, supervised the fieldwork, and participated in writing the manuscript.

\section{Acknowledgments}

The authors wish to thank the Pan-American Health Organization/World Health Organization, and the Spanish Agency for International Cooperation (contract CS ARG/CNT/00302.001) for financial support.

Dr. G. Griemberg was supported by a grant from the University of Buenos Aires (B092).

Dr. S. R. Friedman was supported by a supplement to the National Institute on Drug Abuse (grant R01 DA13128; Networks, Norms, and HIV Risk among Youth) on Networks, Norms, and Risk in Argentina's Social Turmoil.

Dr. S. R. Friedman and Dr. D. Rossi have been partially funded by a Fogarty International Center/NIH grant through the AIDS International Training and Research Program at Mount Sinai School of Medicine - Argentine Program (grant D43TW001037).

The authors thank Dr. Isabel Noguer and Dr. Paloma Cuchí for their encouragement to conduct the study, Dr. Enrique Vázquez for his contributions to the data analysis, Dr. Jag Khalsa for his valuable suggestions, Mr. Gustavo Pérez for his language assistance, and all the volunteers for participating in this study.
3. Weissenbacher M, Rossi D, Radulich G, Sosa-Estani S, Vila M, Vivas E, et al. High seroprevalence of bloodborne viruses among street-recruited injection drug users from Buenos Aires, Argentina. Clin Infect Dis 2003; 37 Suppl 5:S348-52.

4. Sosa-Estani S, Rossi D, Weissenbacher M. Epidemiology of human immunodeficiency virus (HIV)/ acquired immunodeficiency syndrome in injection drug users in Argentina: high seroprevalence of HIV infection. Clin Infect Dis 2003; 37 Suppl 5: S338-42.

5. Rossi D, Pawlowicz MP, Rangugni V, Singh DZ, Goltzman P, Cymerman P, et al. The HIV/AIDS epidemic and changes in injecting drug use in Buenos Aires, Argentina. Cad Saúde Pública 2006; 22:741-50. 
6. Gyarmathy VA, Neaigus A, Miller M, Friedman SR, Des Jarlais DC. Risk correlates of prevalent HIV, hepatitis B Virus, and hepatitis C virus infection among non-injecting heroin users. J Acquir Immune Defic Syndr 2002; 30 Suppl 4:448-56.

7. Neaigus A, Miller M, Friedman SR, Des Jarlais DC. Sexual transmission risk among noninjecting heroin users infected with human immunodeficiency virus or hepatitis C virus. J Infect Dis 2001; 184: 359-63.

8. Howe CJ, Fuller CM, Ompad DC, Galea S, Koblin $\mathrm{B}$, Thomas D, et al. Association of sex, hygiene and drug equipment sharing with hepatitis $C$ virus infection among non-injecting drug users in New York City. Drug Alcohol Depend 2005; 79:389-95.

9. Chitwood DD, Comerford M, Sanchez J. Prevalence and risk factors for HIV among sniffers, short-term injectors, and long-term injectors of heroin. J Psychoactive Drugs 2003; 35:445-53.

10. Council for International Organizations of Medical Sciences/World Health Organization. International ethical guidelines for biomedical research involving human subjects. http://www.cioms.ch/ frame_guidelines_nov_2002.htm (accessed on 27/ Mar/2003).

11. Wiebel W. Identifying and gaining access to hidden populations. In: Lambert E, editor. The collection and interpretation of data from hidden populations. Washington DC: National Institute on Drug Abuse; 1990. p. 4-11. (NIDA Research Monograph Series, 98)

12. Oliveira S, Hacker M, Oliveira M, Yoshida C, Telles P, Bastos F. A window of opportunity: declining rates of hepatitis B virus infection among injection drug users in Rio de Janeiro, and prospects for targeted hepatitis B vaccination. Rev Panam Salud Pública 2005; 18:271-7.

13. Di Martino V, Rufat P, Boyer N, Renard P, Degos F, Martinot-Peignoux M, et al. The influence of human immunodeficiency virus co-infection on chronic hepatitis $\mathrm{C}$ in injection drug users: a longterm retrospective cohort study. Hepatology 2001; 34:1193-9.

14. Osimani ML, Latorre L, editors. Prácticas de riesgo y prevalencia de infecciones por Virus de Inmunodeficiencia Humana (VIH), Hepatitis B (VHB), Hepatitis C (VHC) y T. pallidum (sífilis) en usuarios de cocaína no inyectable. Montevideo: Grupo Editor IDES; 2003.

15. Friedman SR, Jose B, Neaigus A, Goldstein M, Curtis R, Ildefonso G, et al. Consistent condom use in relationships between seropositive injecting drug users and sex partners who do not inject drugs. AIDS 1994; 8:357-61.
16. Zocratto KBF, Caiaffa WT, Proietti FA, CarneiroProietti AB, Mingoti SA, Ribeiro GJC, et al. HCV and HIV infection and co-infection: injecting drug use and sexual behavior, AjUDE-Brasil I Project. Cad Saúde Pública 2006; 22:839-48.

17. Quaglio G, Lugoboni F, Pajusco B, Sarti M, Talamini G, Lechi A, et al. Factors associated with hepatitis $C$ virus infection in injection and non-injection drug users in Italy. Clin Infect Dis 2003; 37 Suppl 1: S33-40.

18. Bastos FI, Lowndes CM, Derrico M, Castello-Branco LRC, Carvalho MIL, Oelemann W, et al. Sexual behavior and infection rates for HIV, blood-borne and sexually transmitted infections among patients attending drug treatment centers in Rio de Janeiro, Brazil. Int J STD AIDS 2000; 11:383-92.

19. McMahon JM, Tortu S. A potential hidden source of hepatitis $\mathrm{C}$ infection among non-injecting drug users. J Psychoactive Drugs 2003; 35:455-60.

20. Post JJ, Dolan KA, Whybin LR, Carter IW, Haber PS, Lloyd AR. Acute hepatitis $C$ virus infection in an Australian prison inmate: tattooing as a possible transmission route. Med J Aust 2001; 174:183-4.

21. Alizadeh AH, Alavian SM, Jafari K, Yazdi N. Prevalence of hepatitis $\mathrm{C}$ virus infection and its related risk factors in drug abuser prisoners in HamedanIran. World J Gastroenterol 2005; 11:4085-9.

22. Friedman SR, Cooper H, Tempalski B, Keema M, Friedman R, Flom P, et al. Relationships of deterrence and law enforcement to drug-related harms among drug injectors in US metropolitan areas. AIDS 2006; 20:93-9.

23. Vignoles M, Avila MM, Osimani ML, Pando M, Rossi D, Sheppard, et al. HIV seroincidence estimates among at-risk populations in Buenos Aires and Montevideo: use of the Serologic Testing Algorithm for Recent HIV Seroconversion (STARHS). J Acquir Immune Defic Syndr 2006; 42:494-500.

24. Des Jarlais DC, Arasteh K, Perlis T, Hagan H, Abdul-Quader A, Heckathorn DD, et al. Convergence of HIV seroprevalence among injecting and noninjecting drug users in New York City. AIDS 2007; 21:231-5.

25. Pechansky F, Woody G, Inciardi J, Surratt H, Kessler F, Von Diemen L, et al. HIV seroprevalence among drug users: an analysis of selected variables based on 10 years of data collection in Porto Alegre, Brazil. Drug Alcohol Depend 2006; 82 Suppl 1: S109-13.

26. Pechansky F, Von Diemen L, Kessler F, Hirakata V, Metzger D, Woody G. Preliminary estimates of human immunodeficiency virus prevalence and incidence among cocaine abusers of Porto Alegre, Brazil. J Urban Health 2003; 80:115-26.

Submitted on $16 /$ Oct/2006

Final version resubmitted on 15/May/2007

Approved on 27/Aug/2007 